\title{
Anti-Oxidant, Anti-Hemolytic Effects of Crataegus aronia Leaves and Its Anti- Proliferative Effect Enhance Cisplatin Cytotoxicity in A549 Human Lung Cancer Cell Line
}

\author{
Islam Omairi ${ }^{1}$, Firas Kobeissy ${ }^{2,3}$, Salam Nasreddine ${ }^{1,4 *}$
}

\begin{abstract}
Objective: For Arabian traditional medicine, Crataegus aronia syn. Azarolus (L) Bosc. ex DC (Rosaceae) is widely used to treat diabetes, sexual weakness, cardiovascular diseases and cancer. The anti-cancerous and antihemolysis effects of the hydroalcoholic extract of this plant have never been investigated before. The present study aims to evaluate the biological activities of the hydroalcoholic extract of Crataegus aronia leaves in combination with cisplatin, one of the most widely employed chemotherapeutics, on A549 human lung cancer cell line. Methods: The anti-oxidant and anti-proliferative activities of leaves, fruits, seeds of $C$. aronia were investigated by DPPH method and MTT assay; respectively. Cell migration activity was investigated by wound healing and by cell aggregation assays. The effect of $C$. aronia in inducing cell cycle arrest along with activating cell apoptosis was evaluated by flow cytometry and Western blot assays, respectively. Results: Our results showed that $C$. aronia leaves (C. aronia L.) had the highest anti-oxidant and anti-proliferative activities. The leaves extract was potent against hemolysis of the human erythrocytes and showed elevated decrease in migration by reducing wound healing migration and by increasing cell aggregation. Finally, C. aronia L. treatment exhibited apoptotic activity on A549 cells by the down-regulation of PARP-1, caspase- 3 and Bcl-2 proteins and by increasing the percentage of A549 cells in sub G0 cell cycle. Moreover, the co-treatment of $C$. aronia L. and cisplatin remarkably sensitised A549 cells to cisplatin. Conclusion: The results suggested that $C$. aronia $\mathrm{L}$. could be used as a potential treatment against human lung cancer exhibiting minimal side effects on human health.
\end{abstract}

Keywords: Crataegus aronia- antioxidant activity- antiproliferative activity- cells migration- cells aggregation

Asian Pac J Cancer Prev, 21 (10), 2993-3003

\section{Introduction}

Cancer is considered the second leading cause of death worldwide accounting for an estimated 18.1 million new cancer cases with around 9.6 million cancer deaths in 2018 (Bray et al., 2018). It is estimated that cancer-related deaths would increase to over 17 million in 2030 (Thun et al., 2009). Cancer diagnosis, death and treatments are strongly varied among countries depending on the environmental factors, economic development and lifestyle factors. Lung cancer is considered a major cause of cancer diagnosis (11.6\% of the total cases) and deaths (18.4\% of cancer deaths) in both sexes combined (Bray et al., 2018). Lung cancer is mainly divided into two key types involving the non-small cell lung cancer (NSCLC) and the small cell lung cancer (SCLC). NSCLC is divided into 3 major subtypes: squamous cell carcinoma, adenocarcinoma and large cell carcinoma. It accounts for $75 \%$ of all lung cancer cases.

Small cell lung cancer (SCLC) accounts for $15 \%$ to $18 \%$ of all lung cancer cases (Miao et al., 2018). Tobacco smoking remains the number one risk factor for developing lung cancer. In the United States, lung cancer mortality rate, caused by cigarette smoking, ranges between $80 \%$ to $90 \%$ (Alberg et al., 2013).

The chemotherapy is the classical treatment for lung cancer and often consists of a combination of drugs. The most common chemical drugs used in lung cancer treatment are cisplatin, gemcitabine, paclitaxel, carboplatin plus docetaxel (Burdett et al., 2008). Since chemotherapy has serious side effects, herbal medicine was used to increase the efficacy of chemotherapy drugs and to reduce their side effects as well as to prolong the patient's survival. In China, more than 133 herbal

${ }^{1}$ Doctoral School of Science and Technology, Research Platform for Environmental Science (PRASE), Faculty of Sciences, Lebanese University, Lebanon. ${ }^{2}$ Department of Biochemistry and Molecular Genetics, Faculty of Medicine, American University of Beirut, Beirut, Lebanon, Lebanon. ${ }^{3}$ Department of Psychiatry, Center for Neuroproteomics and Biomarkers Research, University of Florida, Gainesville, FL, USA. ${ }^{4}$ Department of Biology, Faculty of Sciences-Section I, Lebanese University, Groupe Anti-Cancer Therapeutic Approaches (ATAC), Laboratory Rammal Rammal, Lebanon.*For Correspondence: salam.nasreddine@ul.edu.lb 
supplements have been historically used to treat lung cancer. The most common herbal treatment used alongside chemotherapy for lung cancer are astragalus, Nan Sha Shen and asparagus roots (Jiao et al., 2017). However, in the United States, plant-derived drugs represent about $25 \%$ of the total drugs, compared to countries like India and China where the contribution is $\sim 80 \%$ (Qazi Majaz and Molvi Khurshid, 2016).

In fact, there is a return to traditional herbal medicine to treat different diseases and especially cancer. Since the Mediterranean region is very rich in medicinal plants, Lebanon is considered a promising country for new plant discoveries (Baydoun et al., 2015). The Crataegus aronia syn. Azarolus (L) belongs to the family of Rosaceae; it is one of the most dominant hawthorn species that populated the mountains of the Mediterranean region and has been utilized in traditional medicine against many diseases like sexual weakness, cardiovascular diseases, diabetes and cancer (Ali-Shtayeh et al., 2000; Ljubuncic et al., 2005). Several studies have shown that the high amount of flavonoids and proanthocyanidins in the genus Crataegus are very effective against cardiovascular problems, such as hypercholesterolaemia, hypertension, myocardial injuries and atherosclerosis (Nabavi et al., 2015). In addition, $C$. aronia also has showed to have anti-obesity and hyperglycemic effects (Al-Hallaq et al., 2013). Many phytochemical studies revealed that the Crataegus aronia are rich in phenolic compounds including flavonoids, phenolic and tannins (Amina et al., 2018; Donno et al., 2017), which are known to have anti-inflammatory (Brezani et al., 2018), anti-carcinogenic and anti-antioxidant activities (Newmark, 1996; Pourreza, 2013). However, despite its wide use in traditional medicine, the literature still lacks scientific pieces of evidence about its anticancer effects. In the present study, we aimed to determine the antioxidant and the antihemolytic activity of hydroalcoholic extract of $C$. aronia and to evaluate its anti-migration, anti-invasion and antiaggregation effects on the human lung adenocarcinoma cell line (A549). Also, we aim to evaluated the anticancer activity of cisplatin in combination with $C$. aronia plant extract. Our data are the first to highlight the anti-cancerous activity of C. aronia on human lung adenocarcinoma cell line.

\section{Materials and Methods}

\section{Plant collection and extraction}

Fresh C. aronia plant was collected Almat, Byblos, Mount Lebanon between May 2018 and Jun 2018. A voucher specimen (ul 111) was stored in the hebanium of the Faculty of pharmacy, Lebanese University, Beirut, Lebanon. Professor George TOHME, the herbalist and president of the National Council for Scientific Research (CNRS)-Lebanon, carried out the botanical authentication. Leaves, yellow fruits and seeds of $C$. aronia that were processed. In summary dried plant parts were ground to powder and kept in plastic containers and kept away from light, heat and moisture till use. After that, $10 \mathrm{~g}$ of C. aronia powder plant was kept in $200 \mathrm{ml}$ conical flask to which $100 \mathrm{ml}$ of $70 \%$ ethanol was added. The flasks were kept in a reciprocating shaker for 3 to 4 days for continues agitation at $150 \mathrm{rev} / \mathrm{min}$. The solutions were then filtered and concentrated by rotary evaporator at $40^{\circ} \mathrm{C}$ and lyophilisator, respectively and stored at $-20^{\circ} \mathrm{C}$.

\section{Cells and Cell Culture}

Human lung adenocarcinoma A549 cell line was purchased from the American Type Culture Collection (ATCC, Manassas, VA). A549 cell line was maintained in Dulbecco's Modified Eagle's Medium (DMEM) (SigmaAldrich Co., D0819) with 10\% Fetal Bovine Serum (FBS) (Sigma-Aldrich Co., F9665) and 100U/ml penicillin and $0.1 \mathrm{mg} / \mathrm{ml}$ streptomycin (Sigma-Aldrich Co., P4333). Cells were incubated at $37^{\circ} \mathrm{C}$ in humidified air containing $5 \% \mathrm{CO}_{2}$.

DPPH ( $\alpha, \alpha$-diphenyl- $\beta$-picrylhydrazyl) antioxidant assay

To assess the antioxidant activity of $C$. aronia plant extracts (leaves, fruits and seeds), DPPH radical scavenging activity was performed according to a previous method (Nasreddine et al., 2018). DPPH (Alfa Aesar 44150) is dark-colored crystalline powder-free radical that gives a purple color when dissolved in a solvent. It works by trapping or scavenging other free radicals present in the solution, which will cause the change of the purple color into a pale-yellow color as an indication of the antioxidant activity of the compound tested. Here, $1 \mathrm{ml}$ of each concentration of the plant extract was prepared to which $1 \mathrm{ml}$ of DPPH was added. The control was prepared with $1 \mathrm{ml}$ of DPPH and $1 \mathrm{ml}$ of solvent (ethanol). Samples were kept in the dark for $30 \mathrm{~min}$ and the optical density was measured at $515 \mathrm{~nm}$ wavelength with UV-Vis spectrophotometer. The DPPH scavenging activity of the samples was calculated according to the following equation:

$\%$ Radical scavenging activity $=[($ Abs control - Abs sample)]/ (Abs control)] X 100.

\section{MTT (3-(4,5-Dimethylthiazol-2-yl)-2,5-Diphenyl Tetrazolium Bromide) assay}

A549 cell lines were seeded in a 96-well plate with $10^{4}$ cells per well in $200 \mu \mathrm{l}$ DMEM culture medium with $10 \%$ FBS and $1 \%$ (Pen/Strep). After incubation overnight, cells were treated with different concentrations of $C$. aronia extract $(50,100,150,200,300$ and 500 $\mu \mathrm{g} / \mathrm{ml}$ ) for 24, 48 and $72 \mathrm{hr}$. After incubation time with treatments, $20 \mu \mathrm{l}$ of MTT (3-(4,5-Dimethylthiazol-2yl)-2,5-Diphenyl Tetrazolium Bromide) (Sigma-Aldrich Co., M5655) (5 mg/ml in PBS $1 \mathrm{X})$ reagent is added to each well and left for $3 \mathrm{hr}$ at $37^{\circ} \mathrm{C}$ with $5 \% \mathrm{CO}_{2}$ until a purple precipitate was observed. The MTT was dissolved in $1 \mathrm{X}$ phosphate-buffered saline (PBS) (Sigma-Aldrich Co., D1408). Media was removed delicately and $100 \mu \mathrm{l}$ isopropanol-HCl (MTT solvent) was added to dissolve the purple precipitate (formazan crystals). The resulting purple formazan crystals were dissolved in $100 \mu \mathrm{l}$ isopropanol-HCl. The Optical Density (OD) was read by an ELISA reader at $595 \mathrm{~nm}$ wavelength. Isopropanol$\mathrm{HCl}$ was used as a blank. Percentage of cell viability was calculated according to the following equation: 
Cell viability $(\%)=(\mathrm{OD}$ treated/ OD control $) * 100$. Percentage cytotoxicity was calculated for finding the IC50 value of the concentration required for $50 \%$ cell death by each extract.

\section{Wound healing assay}

Wound healing assay was done to determine the ability of A549 cells to migrate after the treatment with different non-toxic concentrations of $C$. aronia by measuring the distance of the wound formed. Briefly, 7 x $10^{5}$ cells were seeded in a 6-well plate with DMEM medium $(10 \% \mathrm{FBS}$ and $1 \% \mathrm{Pen} / \mathrm{Strep}$ ) and incubate overnight at $37^{\circ} \mathrm{C}$ to reach $90-100 \%$ confluency. After incubation time, the A549 cells were starved in DMEM culture medium without FBS. Using a $200 \mu \mathrm{l}$ tip, a scratch was made as uniformly as possible through the monolayer cells. After that, treatment of different concentrations ( 150 and $300 \mu \mathrm{g} / \mathrm{ml})$ of leaves of $C$. aronia was added. Representative pictures were taken at different time points $(0,2,4,6,8,10,12$ and $24 \mathrm{hr}$ ) using Leica DM IL LED inverted microscope (Wetzlar, Germany Leica Microsystems $\mathrm{GmbH}$ ) equipped with digital imaging system. The distance of the wound at different time points was measured using ImageJ. The results at each time point were compared to $\mathrm{t}=0$ (wound distance at $\mathrm{t}=0$ - wound distance at different time points) and the results were further compared to the control with no treatment, to estimate the migratory potential of the cells. In this technique, the concentrations of the plant extracts used are tested before by MTT assay to be nontoxic to the cells with the selected incubation time.

\section{Aggregation assay}

The aggregation assay was performed according to the published protocol (Al Dhaheri et al., 2013). A549 cells were seeded in a 6 -well plate and detached using $2 \mathrm{mM}$ EDTA in calcium magnesium-free PBS (CMF-PBS). A cell suspension of $1 \times 10^{6}$ cells $/ \mathrm{ml}$ was aliquoted into centrifuge tubes and washed with CMF-PBS. Cells were then resuspended in $1 \mathrm{ml} \mathrm{CMF-PBS}$ with or without leaves of $C$. aronia $(150$ and $300 \mu \mathrm{g} / \mathrm{ml})$ and kept on a rocker for 60 minutes at $37^{\circ} \mathrm{C}$. Cells were fixed with $1 \mathrm{ml}$ of $1 \%$ formaldehyde and pictures were taken under an inverted microscope (Leica Microsystems GmbH, Wetzlar, Germany). Percentage of aggregation was calculated using the following equation:

$\%$ Aggregation $=[(1-\mathrm{Nt} / \mathrm{Nc})] \mathrm{X} 100$, where $\mathrm{Nt}$ and $\mathrm{Nc}$ represent the number of single cells in treated or untreated (control) groups, respectively.

\section{Flow cytometry and cell cycle analysis}

A549 cells were seeded in a 6-well plate with a density of $2.8 \times 10^{5}$ cells per well and incubated overnight until $70 \%$ confluency is reached. Post $24 \mathrm{hr}$ incubation, cells were treated with 150 and $300 \mu \mathrm{g} / \mathrm{ml}$ of leave extracts of $C$. aronia and incubated for $48 \mathrm{hr}$. Then, cells were removed and fixed with $1 \mathrm{ml}$ of ice-cold $70 \%$ ethanol and kept at $4^{\circ} \mathrm{C}$ until analysis. Fixed cells were washed two times in PBS $1 \mathrm{X}$ and collected by centrifugation before being resuspended in $50 \mu \mathrm{l}$ of $100 \mu \mathrm{g} / \mathrm{ml}$ of RNase A (Sigma-Aldrich Co., R6513) and incubated for $1 \mathrm{hr}$ at $37^{\circ} \mathrm{C}$. Cells were resuspended in $200 \mu \mathrm{l}$ of $50 \mu \mathrm{g} / \mathrm{ml}$ of Propidium Iodide (PI) (Sigma-Aldrich Co., 81845). Cell cycle analysis was determined using the BD FACS Aria cell sorter machine (Guava EasyCyte8 Flow Cytometer; Millipor).

\section{Hemolytic activity}

Hemolytic activity was done according to the protocol of Malagoli, (2007). Briefly, fresh human blood sample was centrifuged at $2500 \mathrm{rpm}$ for $10 \mathrm{~min}$ to separate erythrocytes from the plasma. Erythrocytes were washed three times with $1 \mathrm{X}$ PBS. Discard the supernatant by centrifugation at 2,500 rpm for $12 \mathrm{~min}$ at $4{ }^{\circ} \mathrm{C}$. The erythrocytes were then diluted with $1 \mathrm{X}$ PBS to obtain a suspension of $5 \%$. To $1 \mathrm{ml}$ of the erythrocyte suspension, $50 \mu \mathrm{l}$ of different concentrations of leaves of $C$. aronia extracts were added $(10,20,40,50$ and $100 \mu \mathrm{g} / \mathrm{ml})$. The mixture was incubated at $37^{\circ} \mathrm{C}$ for $1 \mathrm{hr}$ and a half and then the tubes were centrifuged at 2,500 rpm for $10 \mathrm{~min}$ at $4{ }^{\circ} \mathrm{C}$. The optical density (OD) was then measured at 540 $\mathrm{nm}$. Blood alone without treatment was used as negative control, SDS 1\% to check hemolysis of cells and PBS 1X as the blank. Hemolytic levels were calculated as follows:

$\%$ Hemolysis $=[\mathrm{OD}$ of extract $/$ OD of control $] \mathrm{X} 100$.

\section{Anti-hemolytic activity}

For the anti-hemolytic activity assessment, we followed published protocol for anti-hemolytic activity (James and Alewo, 2014). Same steps were performed as the hemolysis assay except adding of $\mathrm{H}_{2} \mathrm{O}_{2}$ to induce hemolysis. Fresh human blood sample was centrifuged at 2,500 rpm for $10 \mathrm{~min}$ to separate erythrocytes from the plasma. Erythrocytes were washed three times with $1 \mathrm{X}$ PBS by centrifugation at 2,500 rpm for $12 \mathrm{~min}$ at $4^{\circ} \mathrm{C}$ and the supernatant was discarded. The erythrocytes were then diluted with PBS to obtain a suspension of 5\%. To $1 \mathrm{ml}$ of the erythrocyte suspension, $50 \mu \mathrm{l}$ of different concentrations of leaves of $C$. aronia extracts were added $(10,20,40,50$ and $100 \mu \mathrm{g} / \mathrm{ml})$. The mixture was incubated for 20 min with the treatment and then $350 \mu \mathrm{l}$ of $\mathrm{H}_{2} \mathrm{O}_{2}$ was added. The mixture was incubated at $37^{\circ} \mathrm{C}$ for $1 \mathrm{hr}$ and a half and then the tubes were centrifuged at $2500 \mathrm{rpm}$ for 10 $\min$ at $4^{\circ} \mathrm{C}$. The optical density (OD) was then measured at $540 \mathrm{~nm}$. Blood alone was used as negative control, $\mathrm{H}_{2} \mathrm{O}_{2}$ $30 \%$ alone as positive control and PBS $1 \mathrm{X}$ as the blank. Anti-hemolytic levels were calculated according to the following equation:

$\%$ of inhibition of hemolysis $=[(\mathrm{OD}$ of control $-\mathrm{OD}$ of extract) / (OD of control)] X 100.

\section{Western blot}

A549 cells were seeded in a 6-well plate with a density of $2.8 \times 10^{5}$ cells per well and incubated overnight. After 24 $\mathrm{hr}$, leaves of C. aronia $(150$ and $300 \mu \mathrm{g} / \mathrm{ml})$ extract were added to the wells and incubated for $48 \mathrm{hr}$. Then, cells were lysed $120 \mu \mathrm{l}$ of lysis buffer (Tris- $\mathrm{HCl} \mathrm{pH}=6.8$, glycerol, $10 \% \mathrm{SDS}$, DTT and protease inhibitor) for $20 \mathrm{~min}$ at $4{ }^{\circ} \mathrm{C}$. After centrifugation, the supernatant was collected and stored at $-20^{\circ} \mathrm{C}$ until use. Protein quantification was done 
according to Bradford assay. A total of $20 \mu \mathrm{g}$ of protein samples were mixed with Laemli and $\beta$-mercaptoethanol and denatured at $95^{\circ} \mathrm{C}$ for $10 \mathrm{~min}$. Then, $20 \mu \mathrm{l}$ of each sample were loaded to a $10 \%$ SDS-PAGE gel. Proteins were then transferred to a nitrocellulose membrane for $2 \mathrm{hr}$. The membrane was then fixed with 5\% non-fat dry milk for $2 \mathrm{hr}$ and incubated with rabbit primary antibodies for $2 \mathrm{hr}$ or overnight. All the primary antibodies are Rabbit IgG anti-human: poly-adenosine diphosphate (ADP) ribose polymerase-1 (PARP-1) (Cell Signaling, 9542) (dilution 1/1,000), caspase-3 (Santa Cruz, sc7148) (Dilution 1/1,000), B-cell lymphoma 2 (Bcl-2) (Abcam, ab32124) (dilution 1/5000), Bcl-2 associated $\mathrm{X}$ protein (Bax) (Abcam, ab32503) (dilution 1/2,000) and GAPDH (Abcam, ab181602) (dilution 1/10,000). The secondary antibody Horseradish Peroxidase (HRP)conjugated Goat anti-rabbit IgG (Abcam, ab6721) (dilution $1 / 5,000$ ) was used to detect the proteins of interest. The bound secondary antibody was detected with ECL Plus kit according to the manufacturer's protocol. The autoradiographs obtained were scanned using the Chemidoc imaging system (Bio-Rad) and the intensity level of the bands was quantified using Image $J$ software 1.48 (National Institutes of Health, Bethesda, MD, USA). All bands were normalized to GAPDH loading control.

\section{Statistical analysis}

Data were expressed as mean \pm standard error of the mean (SEM). The difference between two groups was determined by One-way Anova followed by Bonferroni test to calculate values (p). All statistical analyses were performed using Graphpad Prism 8 software (GraphPad Software Inc., San Diego, CA, USA). A value of $* p<0.05$, $* * \mathrm{p}<0.01$ and $* * * \mathrm{p}<0.001$ were considered to indicate statistical significance.

\section{Results}

Antioxidant activity of different parts of C. aronia using DPPH radical scavenging assay

In order to test the antioxidant activity of $C$. aronia,
DPPH radical scavenging activity was performed as previously mentioned and radical scavenging percentage of each plant part (leaves, seeds and fruits) extract was calculated. The antioxidant activity of the plant extract is considered high when more DPPH radicals (DPPH·) are neutralized and transformed into DPPHH leading to a change in the solution color from dark-violet into pale-yellow or colorless solution. Lower absorbance of the reaction mixture indicated by an increase in the radical scavenging percentage and; thus, higher antioxidant activity. In this study, the results showed an increase in radical scavenging percentage with the increase in the concentration of $C$. aronia extracts (50, $100,150,300$ and $500 \mu \mathrm{g} / \mathrm{ml})$. All the parts of $C$. aronia (leaves, seeds and fruits) showed a significant increase in the radical scavenging activity, with the highest percentage of antioxidant capacity in the leaves of $C$. aronia reaching $70 \%$ of free radical scavenging activity at $500 \mu \mathrm{g} / \mathrm{ml}$ with an $\mathrm{IC}_{50}$ of $14.66 \pm 1.166 \mu \mathrm{g} / \mathrm{ml}$ (Figure 1). This potent antioxidant activity of $C$. aronia leaves $(C$. aronia L.) could be attributed to the presence of phenolic compounds and can have therapeutic implications in the future to protect cells and tissues against oxidative damage (Huang et al., 2017).

\section{C. aronia plant extract reduce cell viability of lung cancer cell line}

A549 cell line was treated with increasing concentrations of different parts of $C$. aronia (leaves, seeds and fruits) for 24, 48 and $72 \mathrm{hr}$. MTT experiment was done as previously described and cell viability was assessed according to the formula mentioned above. Cell morphology and the number of A549 cells after their treatment are presented in Figure 2. The results showed that the leaves of $C$. aronia decreased the cell viability of A549 significantly at 200, 300 and $500 \mu \mathrm{g} / \mathrm{ml}$ concentrations after 48 and $72 \mathrm{hr}$ of treatment, whereas no decrease in cell viability was observed at lower concentrations. While for the seeds of $C$. aronia, there was a significant decrease in cell viability of A549 cell line only at $500 \mu \mathrm{g} / \mathrm{ml}$ of treatment at all time points and no

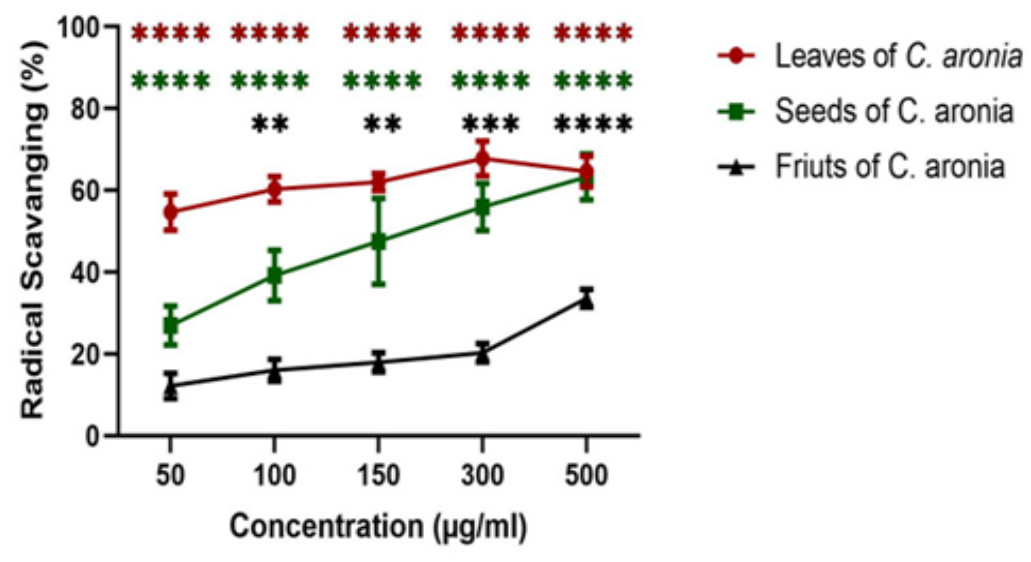

Figure 1. Antioxidant Activities of Ethanol Extracts of $C$. aronia. The percentages of radical scavenging activity of different concentrations $(50,100,150,300$ and $500 \mu \mathrm{g} / \mathrm{ml})$ of leaves, seeds and fruits of $C$. aronia plant extracts were measured by DPPH radical scavenging assay. Data are presented as the mean \pm SEM for three independent experiments $(* * \mathrm{p}<0.01, * * * \mathrm{p}<0.001, * * * * \mathrm{p}<0.0001)$. 

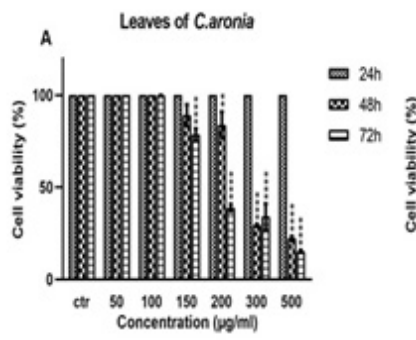

D

Control
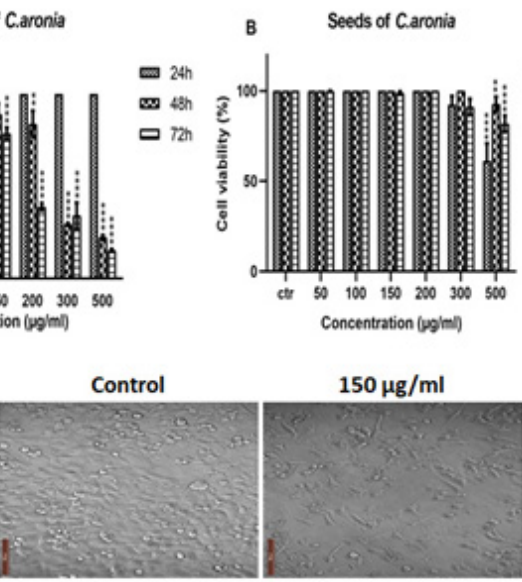

$48 \mathrm{~h}$

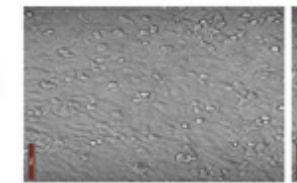

$150 \mu \mathrm{g} / \mathrm{ml}$
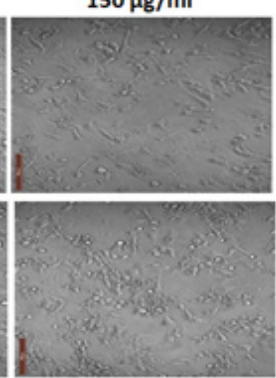

c Fruits of Caronia

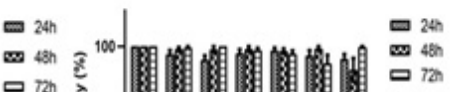

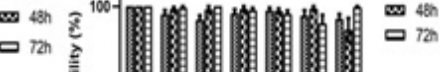

ชู

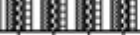

to $50 \quad 100 \quad 150 \quad 200 \quad 300 \quad 500$

Concentration (ug/mi)
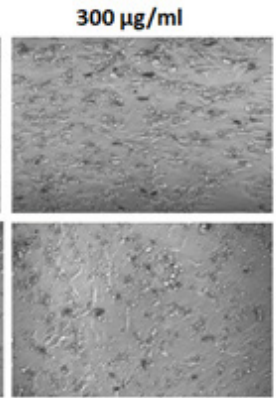

Figure 2. Cell Viability of A549 Lung Cancer Cell Line after C. aronia Treatment was Evaluated by the MTT Assay. (A-C) A549 cells were treated with the indicated concentrations of leaves (A), seeds (B) and fruits (C) of C. aronia ethanol extracts for 24, 48 and $72 \mathrm{hr}$. (D). Microscope view of A549 cells after 24 and $48 \mathrm{hr}$ of treatment with leaves of C. aronia $(150$ and $300 \mu \mathrm{g} / \mathrm{ml}$ ). The morphology of A549 cells was visualized under light microscope (magnification, $\mathrm{x} 400)$. Data are presented as the mean \pm SEM for three independent experiments $(* * \mathrm{p}<0.01, * * * * \mathrm{p}<0.0001)$.
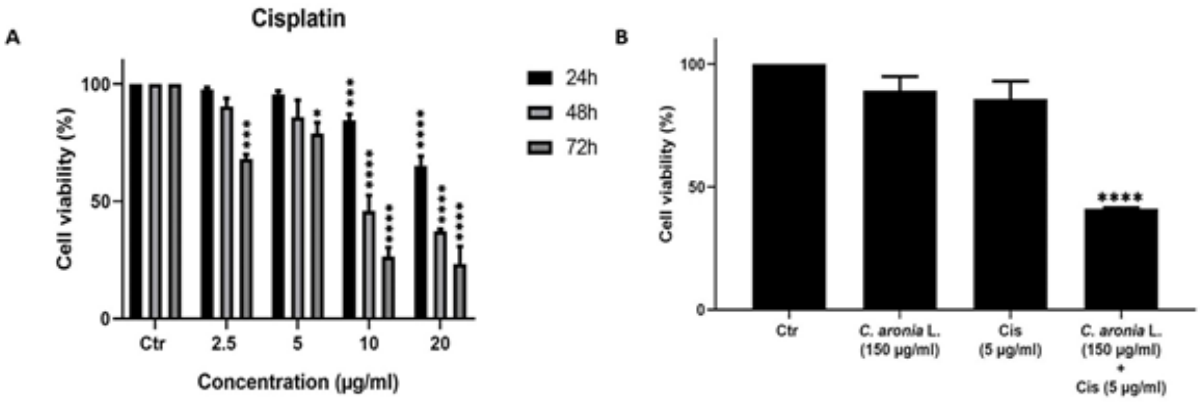

Figure 3. Cell Viability of A549 Lung Cancer Cell Line after C. aronia L. extract and/or Cisplatin Treatment was Evaluated by the MTT Assay. (A) A549 cells were treated with different concentrations of cisplatin (2.5, 5, 10 and 20 $\mu \mathrm{g} / \mathrm{ml}$ ) for 24, 48 and $72 \mathrm{hr}$. (B) A549 cells were treated for $48 \mathrm{hr}$ with the indicated concentrations of cisplatin (Cis) and $C$. aronia leaves $(C$. aronia $L$.) separately and with combination of Cis and C. aronia $\mathrm{L}$. Data are presented as the mean \pm SEM for three independent experiments $(* p<0.05, * * * p<0.001, * * * * p<0.0001)$.

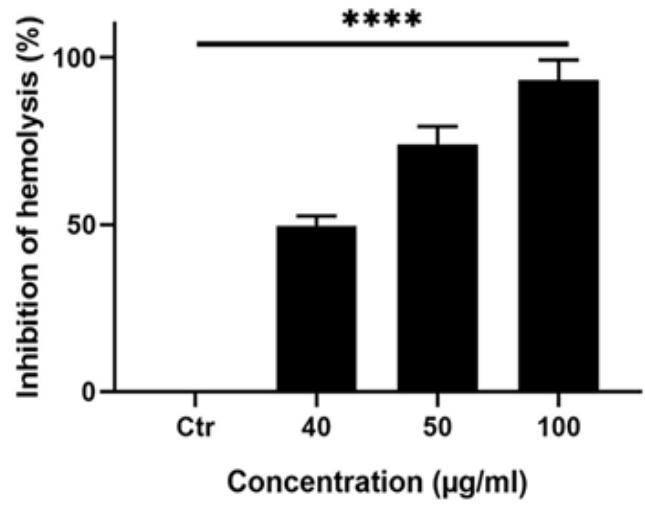

Figure 4. Effect of $C$. aronia Leaves Extract Against Hemolysis in Human Erythrocytes. The human erythrocytes were treated with different concentrations of C. aronia L. (40, 50 and $100 \mu \mathrm{g} / \mathrm{ml})$ in the presence of $\mathrm{H} 2 \mathrm{O} 2$-induced hemolysis of erythrocytes. Data are presented as the mean \pm SEM for three independent experiments $(* * * * \mathrm{p}<0.0001)$. decrease at all in cell viability was observed in fruits of $C$. aronia (Figure $2 \mathrm{~A}, \mathrm{~B}$ and $\mathrm{C}$ ). This indicates that $C$. aronia has a dose and time-dependent effect on the viability of A549 cells. In order to determine the concentration required to achieve a $50 \%$ inhibition of A549 cells induced by $C$. aronia, the dose-response curve was plotted. The $\mathrm{IC}_{50}$ values of $C$. aronia $\mathrm{L}$. extract are $259 \pm 2.41 \mu \mathrm{g} / \mathrm{ml}$ and $195 \pm 2.29 \mu \mathrm{g} / \mathrm{ml}$ at 48 and $72 \mathrm{hr}$, respectively. According to the results obtained, the leaves of $C$. aronia (150 and 300 $\mu \mathrm{g} / \mathrm{ml})$, which have the highest anti-proliferative activity, were chosen for further experiments on A549 cell line.

\section{Cisplatin reduces cell viability in lung cancer}

Cisplatin (Cis) is a conventional chemotherapy used to treat various cancers (Dasari and Tchounwou, 2014), including lung cancer (Hotta et al., 2004). Cisplatin was used in many studies to induce an anti-proliferative effect against A549 lung cancer with an IC50 of $10 \mu \mathrm{M}$ after treatment for $48 \mathrm{hr}$ (Tseng et al., 2016). Our purpose was 

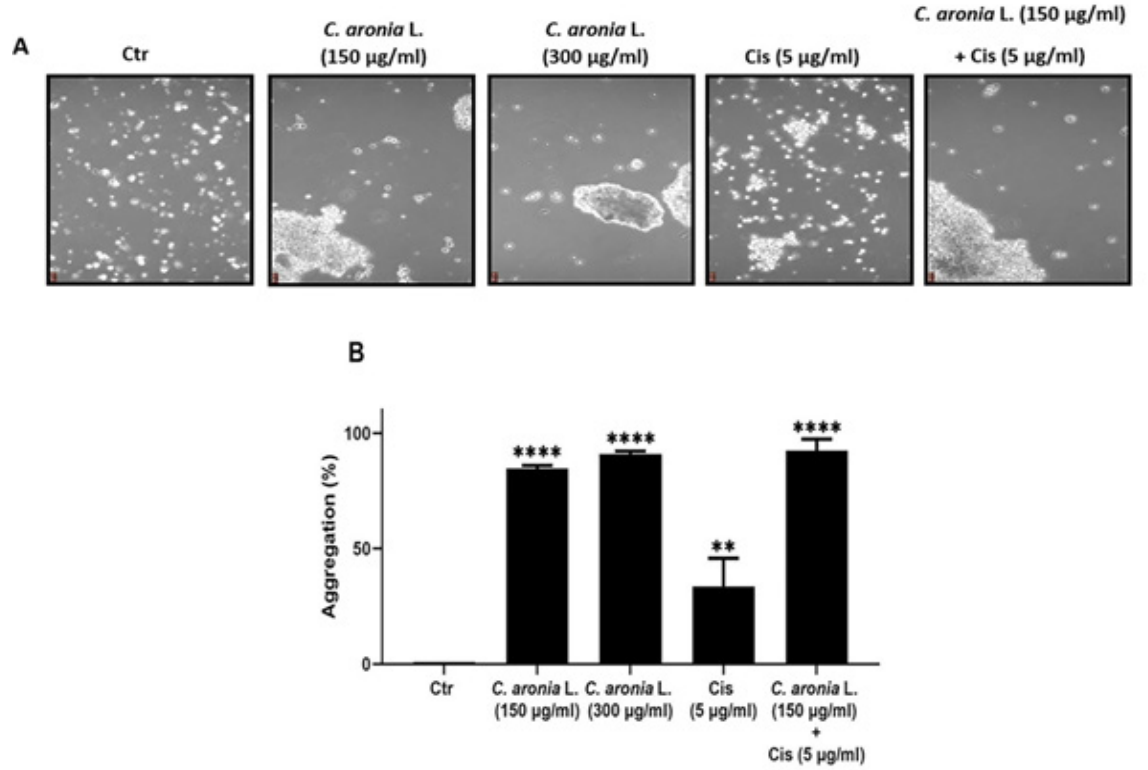

Figure 5. Effect of C. aronia L. in Aggregation of Human Lung Cancer Cell Line (A549). (A) A549 were treated for $1 \mathrm{hr}$ with the indicated concentrations of Cis and $C$. aronia L. separately and with the combination of Cis and $C$. aronia L. A549 cells were photographed with light microscope at x100 magnification. (B) The histogram represents the percentage of aggregation of A549 cells in the presence of $C$. aronia L. extract and/or Cis. The \% of aggregation is calculated as described in material and methods. Data are presented as the mean \pm SEM for three independent experiments $(* * \mathrm{p}<0.01, * * * * \mathrm{p}<0.0001)$.

to see the effect of cisplatin in A549 cell line. A549 cell line was treated with different concentrations of cisplatin $(2.5,5,10$ and $20 \mu \mathrm{g} / \mathrm{ml})$ at 24,48 and $72 \mathrm{hr}$ time points (Figure 3A). As shown in Figure 3A, cisplatin inhibited the proliferation of the lung cancer cell line in a concentrationand time-dependent manner. The results obtained showed that the treatment of A549 cell line with cisplatin have an IC50 of 24.73, 9.56 and $4.72 \mu \mathrm{g} / \mathrm{ml}$ at 24,48 and $72 \mathrm{hr}$ as shown in Figure 3A. We then used the recommended low concentration of cisplatin $(5 \mu \mathrm{g} / \mathrm{ml})$ for further trials in A549 cell line. These results led us to study the effect of cisplatin in combination with $C$. aronia $\mathrm{L}$.
Co-treatment with cisplatin/C. aronia leaves has a synergistic inhibitory effect on A549 cell viability

The literature lacks any study that provides the combinational effect of $C$. aronia plant extracts and cisplatin. Due to the anticancer effect of the $C$. aronia leaves on A549 cell line, we hypothesized that an additional effect might appear when combined with cisplatin. To determine whether the combination of cisplatin and $C$. aronia L. extract may have a more significant anti-cancer effect on A549 cell line than a single treatment, A549 was treated for $48 \mathrm{hr}$ with a low-dose of cisplatin $(5 \mu \mathrm{g} / \mathrm{ml})$ in combination with $150 \mu \mathrm{g} / \mathrm{ml}$ of $C$. aronia leaves. These
A
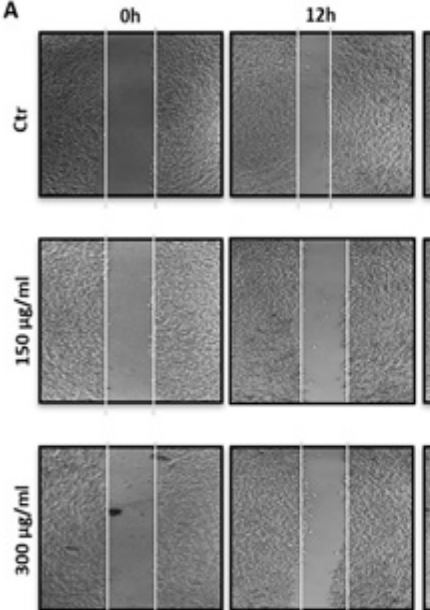

$24 \mathrm{~h}$
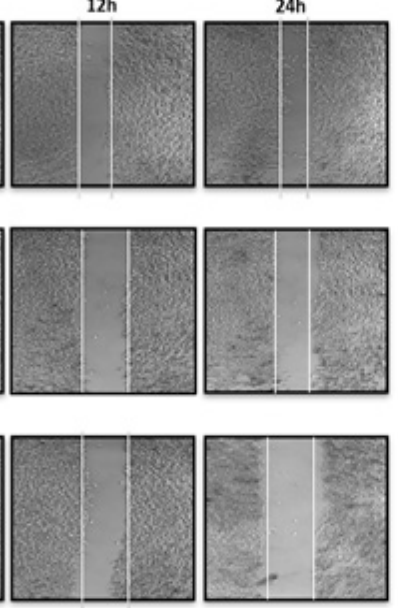

Figure 6. Effect of $C$. aronia Leaves Extract on A549 Cell Migration. (A) Wound healing assay of A549 cells treated with $C$. aronia L. (150 and $300 \mu \mathrm{g} / \mathrm{ml})$ at 0,12 and $24 \mathrm{hr}$ after performing the scratch. A549 cells were photographed with light microscope at $\times 40$ magnification. (B) Histogram represents the distance $(\mu \mathrm{m})$ that the A549 cells have migrated after treatments in 12 and $24 \mathrm{hr}$. Data are presented as the mean $\pm \mathrm{SEM}$ for three independent experiments $(* \mathrm{p}<0.05, * * \mathrm{p}<0.01)$. 


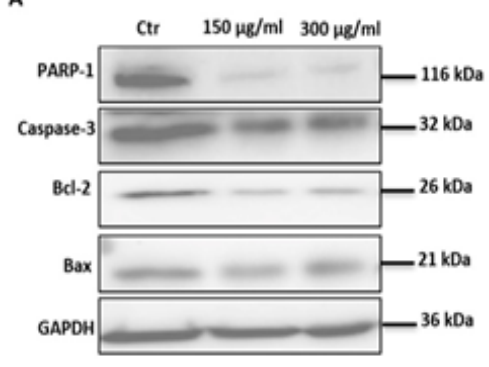

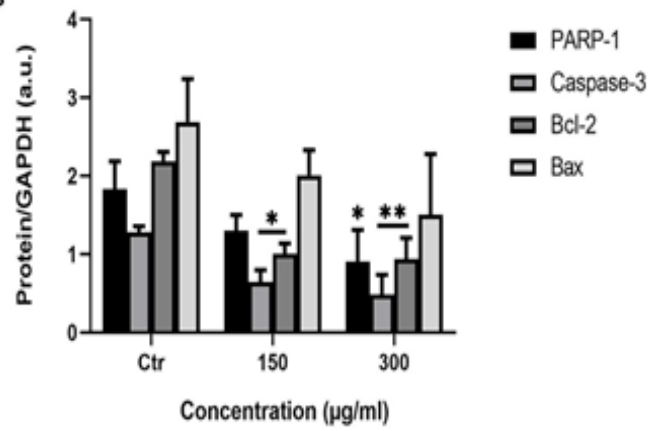

Figure 7. Effect of C. aronia L. on the Expression of PARP-1, Caspase-3, Bcl-2 and Bax Proteins in A549 Cells. (A) Representative western blot showing expression of target proteins in A549 cells exposed to C. aronia L. (150 and 300 $\mu \mathrm{g} / \mathrm{ml}$ ) extract. Levels of proteins were adjusted to the GAPDH protein (housekeeping gene). (B) The expression of proteins was normalized to the GAPDH, and the ratios were presented in arbitrary units (a.u.). Protein band intensity of target proteins was measured by ImageJ software. Data are presented as the mean \pm SEM for 3 independent experiments.

doses of cisplatin and plant extract were chosen based on MTT assay results that showed a low level of toxicity of these concentrations on A549 cell line. After 48 hr of A549 cells treatment with $C$. aronia L. extract $(150 \mu \mathrm{g} / \mathrm{ml})$ and cisplatin $(5 \mu \mathrm{g} / \mathrm{ml})$, the cell viability decreased to $89.15 \%$ and to $85.88 \%$, respectively (Figure 3B). However, cell viability of A549 was dramatically decreased to $41.14 \%$ after co-treatment with cisplatin and $C$. aronia leaves (Figure 3B). These results showed that the leaves of $C$. aronia boosted the cytotoxic effect of cisplatin against A549 cells.

Anti-hemolytic activity of C. aronia leaves extract in human red blood cells

As the typical route of drug administration is systemically by infusion, it is important to monitor if $C$. aronia L. extract has any effect on human Red Blood Cells (RBCs) hemolysis. To assess if the extract can induce hemolysis in human blood RBCs, hemolysis assay was conducted. The results showed that $C$. aronia L. extracts do not cause hemolysis for human RBCs (data not shown) and thus, anti-hemolysis assay can be performed. Anti-hemolysis assay was performed as previously described (James and Alewo, 2014); in brief fresh human blood samples were incubated with the extract for $20 \mathrm{~min}$ with $C$. aronia $\mathrm{L}$. followed by the addition of $\mathrm{H}_{2} \mathrm{O}_{2}$, which is the agent that causes hemolysis. This is done to see if these extracts will inhibit the function of $\mathrm{H}_{2} \mathrm{O}_{2}$. Blood samples were incubated with 40,50 and $100 \mu \mathrm{g} / \mathrm{ml}$ of $C$. aronia L. extract for 20 min after which $\mathrm{H}_{2} \mathrm{O}_{2}$ was added. The results showed than the percentage of inhibition of hemolysis increase with increasing concentrations of

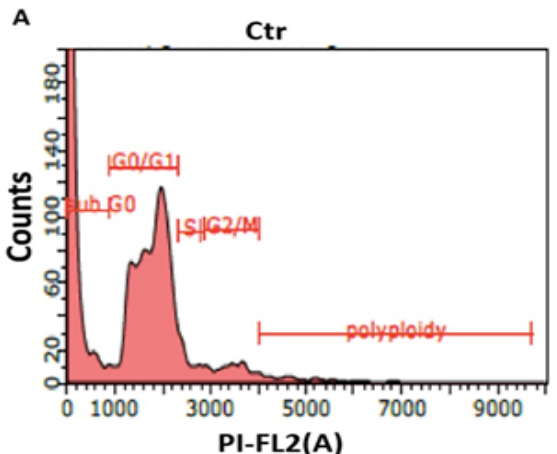

B

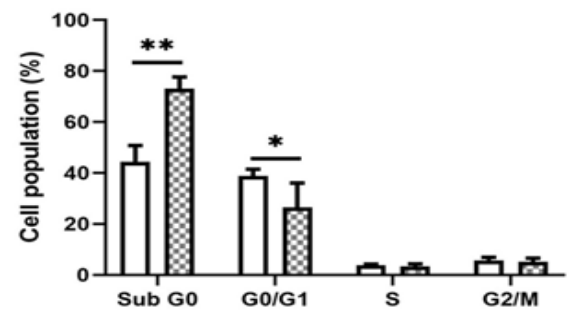

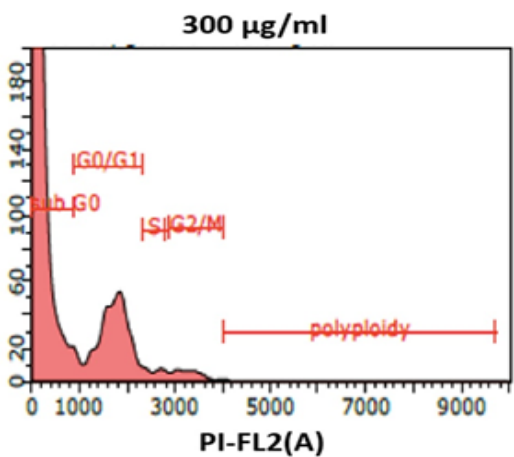

$$
\begin{aligned}
& \text { 다 } \\
& \text { 다 } 300 \mu \mathrm{g} / \mathrm{ml}
\end{aligned}
$$

Figure 8. Effect of $C$. aronia L. on the Cell Cycle Phase Distribution. (A) DNA content of A549 cells treated with C. aronia $\mathrm{L}$. $(300 \mu \mathrm{g} / \mathrm{ml})$ for $48 \mathrm{hr}$ was analysed by propidium iodide (PI) staining. The cell cycle distribution is quantitatively measured by using flow cytometry. (B) The values of the histogram indicate the percentage of cells (before and after treatment) in the indicated phases of the cell cycle. Data are presented as the mean $\pm \mathrm{SEM}$ for three independent experiment. 
the $C$. aronia L. extract (Figure 4). The $\%$ of inhibition of hemolysis has been increased by $86.8 \%$ at $100 \mu \mathrm{g} /$ $\mathrm{ml}$ of the $C$. aronia L. extract (Figure 4). These results confirm that the $C$. aronia L. extract has an excellent antihemolysis effect in human RBCs.

\section{C. aronia leave extracts increase the aggregation of A549 cells}

When cancer cells undergo metastasis, they lose their ability to adhere to each other so they can invade other organs (Leber and Efferth, 2009). When cancer is treated with chemotherapeutic drugs, the adhesion of cells should increase so the metastasis decreases (Larzabal et al., 2013). To determine whether our extract has an effect on the aggregation of these cells, aggregation assay was performed. Single cells number in control and in each treatment were assessed and aggregation percentage was calculated in each condition and compared to the control as previously described. After $1 \mathrm{hr}$ of A549 cells treatment with $150 \mu \mathrm{g} / \mathrm{ml}$ and $300 \mu \mathrm{g} / \mathrm{ml}$ of $C$. aronia L. extracts, the percentages of cells aggregation increased to $84.67 \%$ and to $90.95 \%$, respectively (Figure 5A, B). However, the percentage of cell aggregation of A549 is $33.61 \%$ after treatment with cisplatin alone $(5 \mu \mathrm{g} / \mathrm{ml})$ and become $92.40 \%$ after the co-treatment with cisplatin $(5 \mu \mathrm{g} / \mathrm{ml})$ and C. aronia L. (150 $\mu \mathrm{g} / \mathrm{ml})$ (Figure 5A, B). These results showed that the $C$. aronia L. extract dramatically increased the percentage of A549 lung cancer cells aggregation.

\section{C. aronia leave extracts decrease the migration ability of A549 cells}

Our previous results indicated that $C$. aronia $\mathrm{L}$. extracts had an effect on cell aggregation, we hypothesized that these extracts would exhibit anti-metastasis effect. For this purpose, we performed the wound-healing migration assay with two non-toxic concentrations of C. aronia L. extract $(150 \mu \mathrm{g} / \mathrm{ml}$ and $300 \mu \mathrm{g} / \mathrm{ml})$ for $2,4,6,8,10,12$ and $24 \mathrm{hr}$. No detectable changes in distance were observed for cell migration within the first $10 \mathrm{hr}$ (data not shown). As shown in Figure 6, the treatment of A549 cells with C. aronia L. extract significantly inhibited the cellular migration in concentration- and time-dependent manner. This data show that the $C$. aronia $\mathrm{L}$. inhibits cellular migration of A549 cells.

\section{C. aronia leave extracts induce apoptosis in A549 cells}

PARP-1, caspase-3, Bcl-2 and Bax proteins are considered as protein hallmarks of apoptosis. To check if the $C$. aronia L. induce A549 cell death after $48 \mathrm{hr}$ of treatment via apoptotic machinery, we assessed the levels of PARP-1, caspase-3, Bcl-2 and Bax proteins by Western blotting analysis.

Poly (ADP-ribose) polymerase-1 (PARP-1) is a DNAbinding enzyme involved in DNA damage processing, genetic stability and apoptosis. During the execution phase of apoptosis, PARP-1 is specifically proteolyzed by caspase-3 (Amours et al., 2001). The activation of caspase- 3 is a central event in the process of apoptosis (Thornberry and Lazebnik, 1998; Wolf and Green, 1999). Caspase-3 protein is proteolytically activated. When DNA is damaged in the cell, p53 expression will rise, leading to the increase in Bax protein expression, which is a proapoptotic protein of Bcl-2 family proteins member, which will form a channel in the mitochondria and causes the release of cytochrome c, eventually leading to apoptosis. Unlike Bax, Bcl-2 is an anti-apoptotic member of Bcl-2 family proteins; $\mathrm{Bcl}-2$ inhibits the release of cytochrome c from the mitochondria, thus inhibiting apoptosis (Adams and Cory, 2018). If our treatment has an effect on apoptosis, we should notice a decrease in the amounts of full length PARP-1 and caspase-3 and also in Bcl-2 and an increase in the amount of Bax. For full length PARP-1 and full-length caspase 3 and $\mathrm{Bcl}-2$ proteins the results showed a significant decrease in their expression in A549 cells treated with C. aronia L. for $48 \mathrm{hr}$ (Figure 7A, B). The level of Bax protein was unaltered (Figure7). These results indicated that $C$. aronia $\mathrm{L}$. induced apoptosis through PARP-1, caspase-3 and Bcl-2.

Detection of apoptosis induced by C. aronia L. by flow cytometry assay

Western blot results indicate that the $C$. aronia $\mathrm{L}$. induce apoptosis. To confirm these results, we also observed the induction of apoptosis via a propidium iodide (PI)/RNase A Staining Buffer which is analyzed by flow cytometry. As shown in Figure 8, flow cytometry analysis indicates that the treatment of A549 cells with $300 \mu \mathrm{g} /$ $\mathrm{ml}$ of $C$. aronia $\mathrm{L}$. extract for $48 \mathrm{hr}$ induces apoptosis by increasing the percentage of A549 cells in sub G0 (from $44.31 .8 \%$ to $73.04 \%$ ) and by decreasing the percentage of A549 cells in G0/G1 (from $38.87 \%$ to $26.48 \%$ ) compared to control A549 cells exposed only to DMSO (Dimethyl Sulfoxide). Since no significant change is observed in the cell population of $\mathrm{S}$ phase or G2/M phase, it is suggested that $C$. aronia $\mathrm{L}$. do not exhibit a cytostatic activity.

\section{Discussion}

In the last few years, cancer has become the second cause of death worldwide (Bray et al., 2018). The high rates of deaths caused by cancer referred to the difficulty of its diagnosis in the early stages, excluding breast cancer, in addition to the high speed of cancer progression, metastasis and resistance to treatments (Al-Azri, 2016). Lung cancer and especially the non-small cell lung adenocarcinoma is considered the most abundant cancer worldwide for both males and females (de Groot et al., 2018). The high risks of lung cancer can usually be caused by industrial pollution, by life style and mostly by smoking including passive smoking (Al-Azri, 2016).

Based on the stage of lung cancer, chemotherapy, radiotherapy and surgery are the main lung cancer treatments. Since chemotherapy and radiotherapy with their side effects are not enough to fight cancer, the actual medicine returns to traditional herbal medicine to find plants with high treatment efficiency and with low side effects which can increase the survival rate of a patient with cancer.

Crataegus genus is well known as hawthorns that belong to the Rosaceae family. This genus is mainly distributed in the Northern hemisphere all over Asia, Europe and North Africa. The Crataegus genus has 
approximately 1,000 species identified worldwide (Liu et al., 2010; Wen et al., 2015). The main focus of this study was on the Crataegus aronia hawthorn species that dominates the Arab countries. Besides its ornamental uses, $C$. aronia has been utilized in traditional medicine in treating of many disorders such as diabetes, hyperglycemia, cardiovascular diseases (CVD), cancer and sexual weakness (Ali-Shtayeh et al., 2000; Ljubunic et al., 2005; Al-Hallaq et al., 2013). However, despite its wide use in traditional medicine, there are a few reports in the literature displaying the anti-cancer effects of $C$. aronia.

We begin our study by evaluating the antioxidant activity of the hydroalcoholic extract of $C$. aronia (leaves, fruits, seeds) because it is widely highlighted in literature that the compound with strong antioxidant property will, in general, have potential anticancer effect since the free radicals have a role in cancer development (Kaur and Kapoor, 2001). A study shows that the water extract of leaves and fruits of $C$. aronia have a significant antioxidant activity (Nabavi et al., 2015). Our data indicate that hydroalcoholic extract of $C$. aronia leaves have the highest antioxidant activity. A study was done to evaluate the effect of hydroalcoholic extract of $C$. aronia on human liver cancer cell line (HepG2) by MTT assay. The results have shown that the $C$. aronia has a significant effect on HepG2 just with high concentration $500 \mu \mathrm{g} / \mathrm{ml}$ after 24 and $72 \mathrm{hr}$ of treatments (Kmail et al., 2015). Another study on the ethyl acetate extract of $C$. aronia has shown that it inhibited both human colorectal cancer cell lines HT-29 and HCT-116 cell lines proliferation in a dose dependent manner (Mustapha et al., 2016). To prove the anticancer effect of hydroalcoholic extract of $C$. aronia, we have studied the anti-proliferative activity of $C$. aronia (leaves, fruits, seeds) to show that if there is a correlation between antioxidant and antiproliferative of cancer cells. Cell viability assay was carried out using MTT assay in human lung cancer cell line (A549), like antioxidant, our results show that the $C$. aronia $\mathrm{L}$. have the highest inhibition of viability on A549 cell line. This intense antiproliferative and antioxidant activity of $C$. aronia could be attributed to phenolic compounds presence (Šavikin et al., 2014). Here, our results show that $C$. aronia may have future therapeutic implications by protecting cells against oxidative stress.

According to the results obtained, the leaves of C. aronia, which have the highest antioxidant and antiproliferative activity, were chosen for further experiments. For cancer treatment, researches have been conducted to combine chemotherapy with plant extracts to decrease the side effects and boost the anticancerous treatment. Cisplatin is one of the most compelling ones between many numerous platinum based-chemotherapy drugs used for lung cancer treatment (Hotta et al., 2004). In this work, we treated the A549 cells for $48 \mathrm{hr}$ with cisplatin, C. aronia L. and combination cisplatin/C. aronia leaves. The results show that the $C$. aronia $\mathrm{L}$. boosted the activity of the low concentration of cisplatin, so the C. aronia L. can be used in combination with cisplatin to treat lung cancer with fewer side effects and offer more effective health benefits than higher-dose of cisplatin.

Chemotherapy is usually performed via intravenous routes which causes hemolysis for the human red blood cells (RBCs). Our data indicated that the percentage of inhibition of hemolysis has been greatly increased by the $C$. aronia leaves. These results make it possible to use the $C$. aronia $\mathrm{L}$. for the treatment of lung cancers by intravenous injection.

Cancer cell migration (metastasis) in patients is a major cause of cancer-related mortality (Talmadge and Fidler, 2010; Zheng et al., 2018). Hence, inhibiting migration is an essential step for the treatment of cancer. Despite progress in research, there are until now limited effective therapies available against the metastatic of lung cancer due to drug resistance and severe side effects (Dasari and Tcgounwou, 2014). For this purpose, we investigated the impact of $C$. aronia L. on the migration ability of A549 cells by using wound-healing assay. We performed this test with concentrations of plant extracts and times of treatment that were non-cytotoxic to A549. The toxicity of treatments was evaluated by MTT assay. The present study demonstrated that $C$. aronia L. suppressed the migration in-concentration and time-dependent manner. In addition, when cancer cells undergo metastasis, they lose their ability to adhere to each other so they can invade other organs of the body. When cancer is treated, the adhesion of cells (aggregation) should increase so the metastasis decrease (Abduljauwad and Ahmed, 2019). To identify if our extract has an effect on the cell-cell adhesion of A549 cells, aggregation assay was performed. The number of single cells in control (without treatment) and in treatment with $C$. aronia $\mathrm{L}$. was counted and the percentage of aggregation was calculated and compared to the control. The results of the present study show that the number of single cells decreased and the cell aggregation percentage increased when cells were treated with $C$. aronia leaves. Taken together, our results demonstrated that the $C$. aronia $\mathrm{L}$. can be used as a potential treatment for lung cancer metastasis owing to its anti-metastatic, antiproliferative and therapeutic effects. Because our data clearly show that hydroalcoholic extract of $C$. aronia L. decreases the viability of A549 cells and because several literatures indicate that natural compounds derived from plants promote cancer cell death through apoptosis induction (Safarzadeh et al., 2014), we have investigated the effect of $C$. aronia L. on apoptosis signaling pathway where there is no study about it. The process of apoptosis occurs normally during the lifetime of an organism, which is regulated by group of proteins. The most proteins that are involved in apoptosis are the Bcl-2 family proteins, falling into pro-apoptotic proteins such as Bax, Bim and Bid and anti-apoptotic proteins such as Bcl-2, Bcl-XL and Mcl-1 (Shamas-Din et al., 2013). Many other factors identified were shown to play a vital role in apoptosis, such as p53, caspase-3 and PARP-1. P53 is a tumor suppressor protein that prevents cell cycle progression and induces apoptosis. P53 is the most studied gene in cancer biology since it is mutated in most types of cancers including lung cancer. When DNA is damaged in the cell, p53 expression will rise, leading to an increase in Bax protein expression, which is a pro-apoptotic protein of Bcl-2 family proteins member, which will form a channel in the mitochondria leading to the release of cytochrome 
c, eventually leading to apoptosis (Chipuk et al., 2004). Unlike Bax, Bcl-2 is an anti-apoptotic member of Bcl-2 family proteins that prevents the release of cytochrome $\mathrm{c}$ from the mitochondria, which will consequently inhibit apoptosis (Papaliagkas et al., 2007).

The activation of caspase- 3 is a central event in the process of apoptosis (Wolf and Green, 1999; Adams and Cory, 2018). The caspase-3 is activated by cleavage. Poly (ADP-ribose) polymerase-1 (PARP-1) functions in the repair of DNA damage by adding poly (ADP ribose) polymers in response to a variety of cellular stresses (Chaitanya et al., 2010).

During the execution phase of apoptosis, pro-caspase 8 is cleaved and is activated, which will then cleave and activate caspase 3 . Cleaved caspase 3 will then cleave PARP-1 (Thornberry and Lazebnik, 1998). Western blot data indicated that $\mathrm{Bcl}-2$ protein expression levels, full length PARP-1 and full-length caspase-3 decreased in A549 cells treated for $48 \mathrm{hr}$ by hydroalcoholic extract of C. aronia L. To confirm the results of the western blot, the effect of $C$. aronia L. on cell cycle distribution was tested by flow cytometry analysis. Treatments that modify the cell cycle reflect the cellular mechanism caused by these treatments, such as apoptosis, necrosis, proliferation, differentiation and cell cycle arrest (Elmore, 2007). The increase of cells in sub G0 was taken to reflect the induction of apoptosis (Thangaraj et al., 2019). The flow cytometry results showed that hydroalcoholic extract of $C$. aronia L., by comparing to control, has apoptosis activity on A549 cells by increasing the percentage of cells in sub G0 phase and by reducing the percentage in G0/G1 phase. These results led us to draw a conclusion that ethanol water extract of $C$. aronia L. decrease the viability of lung cancer cells A549 by apoptosis. All our results encouraged us to evaluate in the future the profile of polyphenols in the hydroalcoholic extract of $C$. aronia leaves that may be responsible for the demonstrated activities.

In conclusion, this study is the first to show that hydroalcoholic extract of $C$. aronia $\mathrm{L}$. can decrease the viability of lung cancer cells A549 by causing apoptosis, which was associated with decrease levels of Bcl-2, full length PARP-1 and full-length caspase-3 proteins. Furthermore, C. aronia L. were able to suppress the A549 migration by decreasing wound closure properties and by increasing a cell-cell aggregation. Results from this work suggest that $C$. aronia L. could be a new natural effective candidate for the treatment of the lung cancer.

\section{Authors' contributions}

IO performed the biological experiments, FK analysed the results and corrected the manuscript, SN performed the plant collection and extraction, conceptualized the study, analysed the results and drafted the manuscript. All authors read and approved the final manuscript.

\section{Abbreviations}

C. aronia L.: C. aronia leaves; SCLC: Small Cell Lung Cancer; NSCLC: Non-Small Cell Lung Cancer; DMEM: Dulbecco's Modified Eagle's Medium; FBS: Fetal Bovine Serum; PBS: Phosphate-Buffered Saline; PI: Propidium Iodide; OD: Optical Density; RBCs: Red Blood Cells;
DMSO: Dimethyl Sulfoxide.

\section{Summary}

The studies showed that $C$. aronia $\mathrm{L}$. had potent antioxidant activities. The leaves extract had a protective effect against human red blood cells hemolysis and showed beneficial effects against human lung cancer cell line (A549) by reducing wound healing migration, by increasing cell aggregation and by exhibition of apoptotic activity.

\section{Acknowledgements}

This work was supported by the Central Administration of the Lebanese University (grant number 4/6132, 2017). We would like to thank Professor Ali Eid for his comments and suggestions.

\section{References}

Abduljauwad SN, Ahmed H (2019). Enhancing cancer cell adhesion with clay nanoparticles for countering metastasis. Sci Rep, 9, 1-12.

Adams JM, Cory S (2018). The BCL-2 arbiters of apoptosis and their growing role as cancer targets. Cell Death Differ, 25, 27-36.

Al-Azri MH (2016). Delay in cancer diagnosis: Causes and possible solutions. Oman Med J, 31, 325-6.

Al Dhaheri Y, Attoub S, Arafat K, et al (2013). Anti-metastatic and anti-tumor growth effects of origanum majorana on highly metastatic human breast cancer cells: Inhibition of NFKB Signaling and Reduction of Nitric Oxide Production. PLoS One, 8, 1-17.

Al-Hallaq EK, Kasabri V, Abdalla SS, Bustanji YK, Afifi FU (2013). Anti-obesity and antihyperglycemic effects of crataegus aronia extracts: In Vitro and in Vivo Evaluations. Food Nutr Sci, 4, 972-83.

Alberg AJ, Brock MV, Ford JG, Samet JM, Spivack SD (2013). Epidemiology of lung cancer: Diagnosis and Management of Lung Cancer, 3rd Ed: American College of Chest Physicians Evidence-Based Clinical Practice Guidelines. Chest, 143, e1S-e29S.

Ali-Shtayeh MS, Yaniv Z, Mahajna J (2000). Ethnobotanical survey in the Palestinian Area: A Classification of the Healing Potential of Medicinal Plants. J Ethnopharmacol, 73, 221-32.

Amina B, Ahmed T, Hamdi B, Chawki B, Salah R (2018). Phytochemical constituents, phenolic contents, and antioxidant activity of Crataegus azarolus extracts. Asian $J$ Pharm Clin Res, 11, 0-4.

Amours DD, Sallmann FR, Dixit VM, Poirier GG (2001). Gain-of-Function of Poly (ADP-Ribose) Polymerase-1 upon cleavage by apoptotic proteases: Implications for Apoptosis. J Cell Sci, 1, 3771-8.

Baydoun S, Chalak L, Dalleh H, Arnold N (2015). Ethnopharmacological survey of medicinal plants used in traditional medicine by the communities of mount hermon, Lebanon. J Ethnopharmacol, 173, 139-56.

Bray F, Ferlay J, Soerjomataram I, et al (2018). Global Cancer Statistics 2018: GLOBOCAN Estimates of Incidence and Mortality Worldwide for 36 Cancers in 185 Countries. $C A$ Cancer J Clin, 68, 394-424.

Brezani V, Smejkal K, Hosek J, Tomasova V (2018). Anti-inflammatory natural prenylated phenolic compounds - potential lead substances. Curr Med Chem, 25, 1094-159. 
Burdett S, Burdett S, Stephens R, et al (2008). Chemotherapy in addition to supportive care improves survival in advanced non-small-cell lung cancer: A Systematic Review and MetaAnalysis of Individual Patient Data from 16 Randomized Controlled Trials. J Clin Oncol, 26, 4617-25.

Chaitanya GV, Alexander JS, Babu PP (2010). PARP-1 Cleavage fragments: Signatures of cell-death proteases in neurodegeneration. Cell Commun Signal, 8, 1-11.

Chipuk JE, Kuwana T, Bouchier-hayes L, et al (2004). Direct activation of Bax by $\mathrm{p} 53$ mediates mitochondrial membrane permeabilization and apoptosis. Science, 303, 1010-4.

Dasari S, Tchounwou PB (2014). Cisplatin in cancer therapy: Molecular mechanisms of action. Eur J Pharmacol, 740, 364-78.

Donno D, Mellano MG, Prgomet Ž, Cerutti AK, Beccaro GL (2017). Phytochemical characterization and antioxidant activity evaluation of mediterranean medlar fruit (Crataegus Azarolus L.): Preliminary study of underutilized genetic resources as a potential source of health-promoting compound for food supplements. J Food Nutr Res, 56, $18-31$.

Elmore S (2007). Apoptosis: A review of programmed cell death. Toxicol Pathol, 35, 495-516.

de Groot PM, Wu CC, Carter BW, Munden RF (2018). The epidemiology of lung cancer. Transl Lung Cancer Res, 7, 220-33.

Hotta K, Matsuo K, Ueoka H, et al (2004). Meta-analysis of randomized clinical trials comparing cisplatin to carboplatin in patients with advanced non-small-cell lung cancer. J Clin Oncol, 22, 3852-9.

Huang CY, Ju DT, Chang CF, Muralidhar P, Velmurugan BK (2017). A review on the effects of current chemotherapy drugs and natural agents in treating non-small cell lung cancer. Biomed, 7, 12-23.

James O, Alewo IM (2014). In vitro antihemolytic activity of gymnema sylvestre extracts against hydrogen peroxide (H2O2) induced haemolysis in human erythrocytes. $\mathrm{Am} J$ Phytomedicine Clin Ther, 2, 861-9.

Jiao L, Dong C, Liu J, et al (2017). Effects of Chinese medicine as adjunct medication for adjuvant chemotherapy treatments of non-small cell lung cancer patients. Sci Rep, 7, 1-12.

Kaur C, Kapoor HC (2001). Antioxidants in fruits and vegetables - The Millennium's Health. Int J Food Sci Technol, 36, 703-25.

Kmail A, Lyoussi B, Zaid H, Saad H (2015). In vitro assessments of cytotoxic and cytostatic effects of Asparagus Aphyllus, Crataegus Aronia, and Ephedra Alata in Monocultures and Co-Cultures of Hepg2 and THP-1-Derived Macrophages. Pharmacogn Commun, 5, 165-72.

Larzabal L, El-Nikhely N, Redrado M, et al (2013). Differential effects of drugs targeting cancer stem cell (CSC) and non-CSC populations on lung primary tumors and metastasis. PLoS One, 8, e79798.

Leber MF, Efferth T (2009). Molecular principles of cancer invasion and metastasis (Review). Int J Oncol, 34, 881-95.

Liu P, Kallio H, Lü D, et al (2010). Acids, sugars, and sugar alcohols in Chinese Hawthorn (Crataegus Spp.) Fruits. J Agric Food Chem, 58, 1012-9.

Ljubuncic P, Portnaya I, Cogan U, Azaizeh H, Bomzon A (2005). Antioxidant activity of Crataegus Aronia Aqueous extract used in traditional Arab medicine in Israel. $J$ Ethnopharmacol, 101, 153-61.

Malagoli D (2007). A full-length protocol to test hemolytic activity of palytoxin on human erythrocytes. Invertebr Surviv J, 4, 92-4.

Miao JL, Cai JJ, Qin XF, Liu RJ (2018). Analysis of the clinicopathological characteristics and risk factors in patients with lung cancer and chronic obstructive pulmonarydisease. Biomed Res Int, 2018, 1-5.

Mustapha N, Pinon A, Limami Y, et al (2016). Crataegus Azarolus leaves induce antiproliferative activity, cell cycle arrest, and ppoptosis in human HT-29 and HCT-116 colorectal cancer cells. J Cell Biochem, 117, 1262-72.

Nabavi SF, Habtemariam S, Ahmed T, et al (2015). Polyphenolic composition of Crataegus Monogyna Jacq.: From Chemistry to Medical Applications. Nutrients, 7, 7708-28.

Nasreddine S, Mcheik A, Khalil M, et al (2018). The Antioxidant, Antibacterial, Antihemolytic and Epithelial Ovarian Cancer. Asian J Sci Technol, 9, 8695-703.

Newmark HL (1996). Plant phenolics as potential cancer prevention agents. Adv Exp Med Biol Diet Phytochem Cancer Prev Treat, 401, 25-34.

Papaliagkas V, Anogianaki A, Anogianakis G, Ilonidis G (2007). The proteins and the mechanisms of apoptosis: A MiniReview of the Fundamentals. Hippokratia, 11, 108-13.

Pourreza N (2013). Phenolic compounds as potential antioxidant. Jundishapur J Nat Pharm Prod, 8, 149-50.

Qazi MA, Molvi KI (2016). Herbal Medicine: A Comprehensive Review. I. Int $J$ Pharm Res, 8, 1-5.

Safarzadeh E, Shotorbani SS, Baradaran B (2014). Herbal medicine as inducers of apoptosis in cancer treatment. $A d v$ Pharm Bull, 4, 421-7.

Šavikin K, Živković J, Zdunić G, et al (2014). Phenolic and mineral profiles of four Balkan indigenous apple cultivars monitored at two different maturity stages. J Food Compos Anal, 35, 101-11.

Shamas-Din A, Kale J, Leber B, Andrews DW (2013). Mechanisms of action of Bcl-2 family proteins. Cold Spring Harb Perspect Biol, 5, 1-21.

Talmadge JE, Fidler IJ (2010). AACR Centennial Series: The Biology of Cancer Metastasis: Historical Perspective. Cancer Res, 70, 5649-69.

Thangaraj K, Balasubramanian B, Park S, et al (2019). Orientin induces $\mathrm{G} 0 / \mathrm{G} 1$ cell cycle arrest and mitochondria mediated intrinsic apoptosis in human colorectal carcinoma HT29 cells. Biomolecules, 9, 1-17.

Thornberry NA, Lazebnik Y. (1998). Caspases: Enemies Within. Science, 281, 1312-6.

Thun MJ, DeLancey JO, Center MM, Jemal A, Ward EM (2009). The global burden of cancer: Priorities for Prevention. Carcinogenesis, 31, 100-10.

Tseng CY, Lin CH, Wu LY, et al (2016). Potential combinational anti-cancer therapy in non-small cell lung cancer with traditional Chinese medicine sun-Bai-Pi extract and cisplatin. PLoS One, 11, 1-16.

Wen L, Guo X, Liu RH, et al (2015). Phenolic contents and cellular antioxidant activity of Chinese Hawthorn 'Crataegus Pinnatifida. Food Chem, 186, 54-62.

Wolf BB, Green DD (1999). Suicidal tendencies: Apoptotic cell death by caspase family proteinases. $J$ Biol Chem, 274, 20049-52.

Zheng G, Ma Y, Zou Y, et al (2018). HCMDB: The Human Cancer Metastasis Database. Nucleic Acids Res, 46, D950-5.

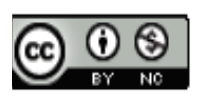

This work is licensed under a Creative Commons AttributionNon Commercial 4.0 International License. 